\title{
O QUE SE ENCOBRE NA VIOLÊNCIA DAS IMAGENS DE PROCRIAÇÃO DOS FILMES DE FICÇÃO CIENTÍFICA*
}

Marika Moisseeff

No último número de 1999 da revista Télérama*, um pequeno artigo sugeria uma lista de fatos que caracterizariam a humanidade do ano 2000, a partir do olhar dos habitantes de algum ano do século XXII. Entre outras coisas notáveis, poderíamos destacar: "No ano 2000, as pessoas eram geradas dentro do ventre de suas mães, como os animais" (Sorg 1999:13; ênfase minha). Retenhamos esse fato: a maternidade, a gravidez, o parto natural, a necessidade de estar no interior de um corpo feminino antes do nascimento rebaixariam a humanidade ao status da animalidade. Esta constatação poderia ser apenas uma anedota, não fosse uma constante nos relatos e nos filmes de ficção científica que têm por tema a procriação. Postulo aqui que as obras de ficção científica correspondem a um tipo de mitologia ocidental contemporânea, no sentido antropológico do termo. Veremos que a análise das mesmas pode iluminar as representações sobre a reprodução, bem como as que dizem respeito às diferenças culturais.

\section{Destino - Admirável mundo novo}

O primeiro mito contemporâneo do gênero "problemática reprodutiva" que o trecho de Télérama nos evoca é Admirável mundo novo, de Aldous Huxley, publicado em 1932. As crianças são fabricadas em frascos de vidro e criadas em centros especializados, ao passo que a viviparidade - termo científico utilizado intencionalmente por Huxley em referência à horrível obrigação animal de passar por um ventre feminino para nascer ${ }^{1}$ — é vista como algo infame e do passado, persistindo apenas em estado de vergonhosa sobrevivência em algumas reservas de selvagens. Nessa utopia, 
o apogeu da civilização corresponde à chegada da esterilização generalizada. A esta sucede o desaparecimento da família, do casamento e de todas as formas de relação de parentesco, que se tornam obscenidades.

Nesse mito de antecipação, a pornografia está vinculada ao parto, e não à sexualidade. Os adultos se entregam sem constrangimentos às atividades eróticas, extasiando-se diante das brincadeiras sexuais das crianças nos pátios de recreação, mas ficam chocados quando algo os faz lembrar da origem vivípara da humanidade. Tal é o caso dos estudantes aos quais se dirige o "Diretor de Incubação e de Condicionamento de Bebês", sobretudo quando são interrogados acerca do significado das palavras pai e mãe:

Fez-se um silêncio embaraçado. Vários jovens enrubesceram. [...] Um deles, por fim, teve a coragem de levantar a mão.

— Os seres humanos, antigamente, eram [...] [Hesitou; o sangue subiu-lhe às faces] Enfim, eram vivíparos [...]. O pobre rapaz estava atrapalhadíssimo.

- Em uma palavra [resumiu o Diretor], os pais eram o pai e a mãe. [Essa indecência, que, na realidade, era ciência, caiu com estrépito no silêncio daqueles jovens, que não ousavam olhar-se] - A mãe [repetiu ele em voz alta, para fazer penetrar bem fundo a ciência] [...] - São fatos desagradáveis, eu sei. Mas é que a maioria dos fatos históricos é mesmo desagradável. [...] [Pois é preciso lembrar que, naqueles tempos de grosseira reprodução vivípara, os filhos eram sempre criados pelos pais, e não em Centros de Condicionamento do Estado].

$[\ldots]$

- Procurem compreender o que significava ter uma mãe vivípara.

Novamente aquela palavra obscena [...]

— Procurem imaginar o que significava "viver em família".

Eles tentaram imaginar; mas, evidentemente, sem nenhum êxito.

— E sabem o que era um "lar"?

Menearam a cabeça.

$[\ldots]$

— [...] Insanamente, a mãe cuidava de seus filhos [seus filhos]... cuidava deles como uma gata cuida de seus filhotes [...] Nosso Freud foi o primeiro a revelar os perigos espantosos da vida familiar. O mundo estava cheio de pais - e, em conseqüência, cheio de aflição; cheio de mães - e, portanto, cheio de toda espécie de perversões, desde o sadismo até a castidade; cheio de irmãos e irmãs, de tios e tias - cheio de loucura e suicídio (Huxley 1998:41-42, 54-57*).

* [N.T.] Citado em português conforme a tradução de Lino Vallandro e Vidal Serrano, Ed. Globo (1941, $2^{\text {a }}$ ed. 2004:34-35 e 47-50). 
No universo sem mães retratado por Huxley, onde um dos lemas favoritos é "cada um pertence a todos", não há casamento nem monogamia: reinam o sexo e a libertinagem. A castidade é vista como uma das piores perversões, pois impede que se atinja a mais nobre experiência espiritual da mais elevada das civilizações: o orgasmo. A castidade remete aos tempos remotos, quando ela consistia no único método eficaz de impedir a reprodução. O prazer sexual e o risco de reprodução são tidos como fundamentalmente antitéticos. Huxley repete: "Civilização é esterilização" (1998: 130,141 [:134,146, na $2^{a}$ ed. brasileira]), ou seja, a erradicação da maternidade. Para ser verdadeiramente humano, inteiramente 'civilizado', é preciso gozar plenamente, isto é, libertar-se do jugo reprodutor. O erotismo é apanágio da humanidade. Ele se inscreve plenamente na cultura, ao passo que a reprodução natural rebaixa ao nível da natureza e, conseqüentemente, da animalidade.

Esse relato de antecipação reflete admiravelmente a evolução das representações acerca das práticas reprodutivas nas sociedades ocidentais, nas quais as atividades eróticas e a procriação remetem a domínios distintos e que devem ser separados: para se realizarem sexualmente, os indivíduos devem se proteger de todo risco reprodutor. Colocam-se então à disposição dos indivíduos púberes métodos contraceptivos eficazes na prevenção da gravidez. A fecundidade das mulheres é assimilada a uma doença que deve ser tratada, desde a puberdade até a menopausa; e quando elas desejam ter filhos devem procurar especialistas, ginecologistas e obstetras, que cuidam mais ou menos exclusivamente da gravidez. A procriação tornou-se o domínio exclusivo da 'assistência médica'.

Portanto, desde 1932, Huxley associa a emancipação sexual ao controle da fecundidade. E, de fato, a liberdade sexual e a igualdade dos sexos devem-se aos métodos desenvolvidos para controlar a fertilidade. Na realidade, a gravidez - fase da reprodução sexuada delegada exclusivamente às mulheres - conduz a uma assimetria entre os sexos que é praticamente intolerável no contexto de uma ideologia baseada na igualdade. Sob essa ótica, a igualdade entre homens e mulheres deve passar pela simetria dos papéis sexuais masculinos e femininos, paternos e maternos. Único obstáculo: a gestação, a necessidade de passar por um corpo materno para nascer e para procriar. Qual seria a solução? Fazer com que os humanos não fossem mais gerados dentro de um corpo feminino, e sim em um ambiente assexuado.

Para tornar-se igual ao homem, a mulher deveria, então, sacrificar aquilo que é exclusivamente seu: a gravidez, e até mesmo a criança. Aqui, já não estamos apenas no nível da utopia: para igualar seu status social ao do homem, muitas mulheres optam por não ter filhos. Na antiga Alemanha 
Oriental, em decorrência de uma onda de desemprego que se sucedeu à reunificação, "centenas delas submeteram-se à esterilização para provar a um eventual empregador que não teriam mais nenhum constrangimento familiar" (Manier 1995:10). Esses dados brutos estão em sintonia com o comentário da fotógrafa Bettina Rheims sobre uma das fotos da sua exposição INRI: "Maria é a nova Eva que salva as mulheres e o mundo, sacrificando seu filho". Arrisquemos interpretar suas palavras. A imaculada concepção, isto é, a disjunção entre a sexualidade e a procriação, combinada com o sacrifício da criança, libertaria os descendentes de Eva, a mãe original, da herança abjeta legada por ela: uma forma arcaica de maternidade. Eva é culpada por ser uma mãe à moda antiga. Maria, a moderna, a substitui para salvar as mulheres e redimir toda a humanidade, assumindo uma reprodução assexuada, sinal precursor do advento de um mundo novo, mais evoluído e civilizado.

\section{Alien, uma iniciação feminina}

Na iconografia hollywoodiana, a imagem da Redenção é representada pela tenente Ripley, heroína de Alien, uma superprodução em quatro episódios ${ }^{2}$ : para salvar a humanidade ameaçada por uma procriação aberrante - alien - ela também deve sacrificar sua progenitura, a filha e o filho que a criatura extraterrestre a obriga a parir. O personagem epônimo, o estrangeiro (alien, em inglês) que a heroína deve combater, tem as características de um predador excepcional - uma espécie de inseto gigante, meio formiga, meio aranha - que transforma suas presas humanas em receptáculos do conteúdo de seus ovos. O único objetivo do monstro é reproduzir-se: nunca o vemos comer, nem copular. A ação predatória de que se trata aqui é a procriação: o bicho não devora as suas vítimas, mas se apropria de seus corpos para procriar. Este invasor é como um câncer: ele extermina de dentro, penetrando o organismo hospedeiro, onde se desenvolve com a velocidade de um raio. A arma suprema do Alien é a gravidez: o conteúdo dos seus ovos é implantado no peito da vítima, através de um órgão projétil cuja extremidade penetra o esôfago; ao cabo de uma gestação toráxica relativamente rápida, o parto do recém-nascido provoca a explosão do hospedeiro.

No universo da ficção científica, Alien poderia ser considerado a seqüência lógica de Admirável mundo novo: tudo acontece como se a procriação natural, sob a máscara do monstro, viesse assombrar os humanos do futuro, que a tinham renegado. Esse tipo de filme antecipa um futuro em que a gestação, privada de seus direitos, tentaria retomar o corpo humano 
— independentemente do sexo — bem como a Terra onde foi condenada e relegada à condição de curiosidade antropológica. E como que por acaso, nesse mundo em que reinam a mistura e igualdade entre os sexos, só uma mulher é capaz de combater essa "sobrevivência" aberrante que é a gestação. Portanto, essa nova forma de mitologia traz à tona, de maneira dramática, o que tende a ficar oculto em nossas sociedades 'igualitárias': uma as simetria primordial que favorece as mulheres ao nível da reprodução e lhes dá poderes específicos e exclusivos. O útero é percebido - e apresentado - como uma caixa de Pandora de onde podem sair mil demônios.

Trazendo a possibilidade de dissociar sexualidade e procriação, os novos modos de reprodução (fecundação in vitru, bebês de proveta, clonagem) sacralizam o campo da obstetrícia e a especificidade da função reprodutora feminina, ou seja, a gestação. Esta pode então se expressar no imaginário cultural sob a forma de entidade autônoma, desligada de seu suporte habitual, a mulher. A gravidez assume o aspecto de uma fera cuja máscara monstruosa esconde os poderes femininos, ocultos e mortíferos, que os aprendizes de feiticeiros tentariam reprimir, ou dos quais procurariam se apropriar. Somos assim levados a assistir ao combate entre A mulher e sua função procriadora, ao qual a epopéia Alien dá todo o destaque. No segundo episódio, Ripley, a heroína, tem de se defrontar e lutar com a rainha alien para impedi-la de inseminar uma menina, Newt, única sobrevivente em um planeta infestado por essas criaturas e que alguns terráqueos haviam tentado colonizar. Com um lança-chamas, Ripley destrói uma colméia com centenas de ovos que se assemelham a úteros gigantes e cuja abertura, a vulva, permite a liberação do órgão intermediário destinado a inseminar os hospedeiros que estiverem ao alcance. Ripley se vê forçada a tirar Newt da crisálida viscosa que a envolve, quando o ovo à sua frente está prestes a romper. Assim, ela impede a entrada precoce da jovem na puberdade, evitando que seja possuída pelas genésicas forças femininas.

A identificação de Ripley com a menina é evidente, e nos será posteriormente confirmada. No segundo episódio, Newt explica que sua mãe sempre lhe dissera que monstros não existiam. No entanto, no último episódio, Alien, a ressurreição, é a voz de Ripley, clonada e grávida de uma pequena rainha, que enuncia essas mesmas palavras. E o episódio anterior, Alien 3, começa com uma cena no interior da nave onde Ripley e Newt, em estado de hipersono, têm diante delas um ovo de alien que começa a se abrir, pressagiando a inseminação mortal que as espreita. De fato, um pouco mais tarde, quando a nave é recuperada, Newt está morta e Ripley, grávida, vai para uma prisão intergaláctica. Os prisioneiros têm duplo cromossomo $Y$, característica associada à natureza do crime que cometeram: estupros 
ou assassinatos violentos de meninas e mulheres. Eles aprenderão, por conta própria, que se enganaram de alvo: as mulheres são apenas o veículo da reprodução natural, atrocidade personificada por Alien. No entanto, quando iniciadas, elas se tornam aptas a sacrificar o poder capaz de possuí-las. Ripley o provará ao atirar-se no aço em fusão, levando consigo para o caldeirão infernal, a coisa que se projeta do seu peito. Combinam-se nela a imagem do Cristo - pois ela se precipita com os braços em cruz — à da Madona com o menino, pois ela comprime contra o peito a rainha que tenta fugir. Cristo e sua mãe, a virgem, nascem de uma concepção miraculosa em que apenas o sobrenatural, Deus, está em jogo, mas não a natureza. Bettina Rheims e Sigourney Weaver estão na mesma sintonia.

A saga de Alien é a alegoria de uma iniciação feminina perpassada pela idéia de que as próprias mulheres devem aprender a sufocar seu poder materno para libertar-se da herança abjeta legada por Eva. Os roteiristas de filmes de ficção científica muitas vezes recorrem a uma trama iniciática inspirada em material etnográfico para pontuar a trajetória dos seus heróis; eles adaptam-na à ideologia ocidental através de metáforas, de concentrados simbólicos. Para permitir a passagem das crianças ao status de adultos, as iniciações masculinas e femininas que ocorrem nas sociedades ditas tradicionais costumam ser compostas de três fases (Van Gennep 1909). A primeira, chamada de separação, consiste em retirar os jovens de seu ambiente habitual: os rapazes são levados para fora da aldeia, para o mato ou a floresta, numa zona não domesticada e considerada selvagem; as moças costumam ser isoladas em local contíguo à aldeia ou em um recinto fechado, dentro de suas próprias casas (Moisseeff 1992;1995). A segunda fase, designada por margem, ocorre nesse local de reclusão e pode durar vários dias, ou anos; nesse espaço 'liminar' [no original, hors société — 'exterior à sociedade'], os jovens têm de submeter-se a uma série de provações que visam transformá-los. A última etapa, a agregação, consiste em reintegrá-los à sociedade de origem, mas com um novo status de homem ou mulher adultos, aptos a casarem e procriarem.

Vejamos a trama do roteiro de Alien.

Uma jovem é retirada de seu meio habitual - a Terra — para ser imersa em um ambiente selvagem, não domesticado - o espaço intergaláctico —, onde deve passar por inúmeras provas que a confrontam com o aspecto da feminilidade ao qual ainda não tivera acesso: a maternidade, que a aterroriza e que adquire para ela a forma horrenda de um monstro. Mas ela é levada a assumi-la progressivamente. Ao longo dos quatro episódios, ela se torna sucessivamente: ama-de-leite de um gatinho, mãe adotiva de uma menina, genitora de uma fêmea e de um macho não humanos. Ripley 
acabará incorporando o lado animal que a torna mulher. Para tanto, deverá submeter-se à última prova — a morte — para renascer das próprias cinzas totalmente metamorfoseada, ainda mais forte e feminina do que antes. Assim, torna-se capaz de abater definitivamente o dragão maternal, o que a autoriza a ser reintegrada à sociedade humana, retornando à Terra.

As iniciações masculinas e femininas que ocorrem em outros contextos culturais - bem reais - legitimam o acesso dos indivíduos a um papel procriador que lhes permite passar do status de criança ao de adulto, apto a ser pai (cf. Moisseeff 1992; 1995; 1998). A iniciação da heroína de Alien, ao contrário, a leva a recalcar seu papel materno: ela o incorpora, mas para melhor silenciá-lo, matando a própria progenitura que gerou. O simbolismo da morte e do renascimento da heroína, dramaticamente veiculado nos dois últimos episódios de Alien, é justamente o que caracteriza a iniciação masculina nesses outros contextos culturais: graças a essa prova, os homens se transformam na própria garantia da fertilidade feminina. Podemos perceber que, se o alvo das iniciações tradicionais e utópicas diz respeito ao futuro da função reprodutora, o tratamento a que se submetem adquire direções contrárias (Moisseeff 2003a; 2003b): no primeiro caso, cabe aos homens, os iniciadores masculinos, favorecer a expressão da maternidade; no segundo, cabe à mulher privar-se desta. Essa inversão simbólica reflete maravilhosamente a transformação das relações entre os sexos que se está produzindo nas sociedades modernas e ocidentais: não caberá à mulher pós-moderna, representada pela estrela de cinema Sigourney Weaver, adotar uma função materna imposta pelos homens, e sim, em uma posição de comando, participar do controle dessa função. As mulheres são vistas como os heróis do futuro, capazes de domar a reprodução.

O monstro de Alien simboliza a alteridade fundamental que opõe os sexos feminino e masculino ao nível da reprodução. A gestação, exclusividade feminina, é mostrada sob a forma de uma infestação capaz de destruir uma humanidade que teria atingido o mais alto grau de evolução tecnológica. Ela é percebida como uma força orgânica sem igual, que investe, hoje, o corpo feminino mas que, no futuro, poderia ser transformada - graças à mais sofisticada tecnologia, isto é, a biotecnologia — em arma biológica suprema que metamorfosearia o inimigo em escravo reprodutor, totalmente submetido às necessidades de reprodução daqueles que o possuíssem. Nessa mitologia, diferentemente dos clássicos filmes de aventura americanos, como os westerns, o inimigo não quer defender seu território, mas invadir o alheio: a Terra e, mais especificamente, o corpo dos terráqueos. Os diferentes significados do termo alien no vocabulário anglo-saxão não deixam dúvida quanto à temível alteridade com que são confrontados os protagonistas dos filmes 
contemporâneos de ficção científica e de terror: "hostil, inaceitável ou repulsivo; diferente ou separado; estrangeiro, supostamente vinculado a seres de outros mundos; espécie vinda de fora que foi introduzida e aclimatada em seu novo habitat" (The Concise Oxford Dictionary*). No primeiro episódio da saga de Alien, este é descrito como um "organismo perfeito", "dotado de extraordinária capacidade de adaptação" e cuja "perfeição só se iguala a sua hostilidade", "um sobrevivente que não é poluído pela consciência, o remorso ou as ilusões da moralidade".

Postulo aqui que esse sobrevivente é a gravidez, símbolo da viviparidade, processo relegado às margens da civilização na utopia de Huxley e na consciência popular, como se vê na prosa do jornalista da revista Télérama, citado logo no início deste trabalho.

\section{Malthus e Darwin: dois precursores da ficção científica contemporânea}

A teoria darwinista da evolução atribui grande importância ao modo de reprodução, na classificação e ordenação das espécies: passamos das espécies inferiores - insetos, peixes, etc. — que põem milhões de ovos, aos mamíferos inferiores, que engendram vários indivíduos por gestação e, em seguida, aos mamíferos mais evoluídos, os primatas, que, geralmente, só têm uma cria por gestação. Thomas Huxley (1825-1895), avô do escritor Aldous Huxley (1894-1963), foi amigo e grande defensor de Darwin. Ele contribuiu - assim como posteriormente seu neto, ainda que de outra maneira - para a difusão e a popularização das idéias darwinistas. Os ocidentais do século XX assimilaram o fato de que, quanto mais evoluída é a espécie em termos biológicos, menos ela procria, tendendo a classificar as diferenças culturais segundo o mesmo raciocínio. O grau de evolução das sociedades é considerado inversamente proporcional à sua taxa de fecundidade: as mais evoluídas em termos tecnológicos são as que têm menos filhos, as mais atrasadas têm mais e permanecem em um estado de incomensurável pobreza em relação aos países industrializados. Essas sociedades mais atrasadas são, inclusive, submetidas a regimes totalitários pouco propícios à expressão da criatividade individual. É nesse sentido que, em Regresso ao admirável mundo novo, Huxley escreve, 26 anos depois da publicação de sua obra-marco, que existe uma relação entre superpopulação e totalitarismo:

* [N.T.] Os termos foram traduzidos para o português a partir da tradução para o francês, pela autora, das definições inglesas. 
[...] a evolução, que conduzirá a superpopulação à ditadura, passando pela agitação, se era antes provável, tornou-se virtualmente certa. Podemos apostar, sem sombra de dúvida, que, dentro de vinte anos, todos os países superpovoados e subdesenvolvidos da Terra estarão submetidos a algum tipo de dominação totalitária — sem dúvida pelo partido comunista (1978 [1958]:21).

No Ocidente, a galopante demografia dos países pobres preocupa as classes privilegiadas desde o surgimento do que Foucault (1976) chamou de biopoder: "uma biopolítica do gênero humano" que, segundo este autor, leva os governantes a realizar, na segunda metade do século XVIII, as primeiras estatísticas sobre a natalidade, a mortalidade e a fecundidade das populações a seu encargo. Podemos supor que a transformação das mentalidades nesse domínio precedeu, como de costume, a adoção de novas medidas políticas ligadas à consciência dos problemas demográficos. O célebre panfleto de Jonathan Swift, intitulado Uma modesta proposta para impedir que as crianças pobres se tornem um fardo para seus pais, publicado em 1729, é um bom exemplo disso, na medida em que o autor sugere, com humor, que se resolva o problema da superpopulação através da antropofagia.

Malthus (1766-1834), ao publicar em 1798 o "Ensaio sobre o princípio da população", seguido em 1803 de uma "exposição de seus efeitos na felicidade humana e dos meios para combater os seus males" (Malthus 1980; 1964), põe lenha na fogueira dos que se preocupam com a prolificidade dos pobres. A simplicidade desse princípio o torna ainda mais poderoso: nos períodos em que não há guerras, fome ou epidemias catastróficas, como a peste, as populações tendem a crescer de maneira excepcional e a esgotar os recursos de determinado território, levando-as a conquistar novos territórios. Darwin, em sua autobiografia, explica que a leitura de Malthus forneceu-lhe a chave para a teoria da evolução. No entanto, ele inverte o raciocínio e atribui valor positivo à prolificidade (Serre 1984). Em A origem das espécies (Darwin 1992 [1859]), as raças são consideradas favorecidas em função de suas capacidades de adaptação e, entre elas, a aptidão para gerar o maior número de descendentes: em dado território, a espécie com maior densidade demográfica tende a eliminar as outras. Compreende-se, assim, o fato de Malthus ter sido um dos inspiradores de Darwin, e que as idéias de ambos tenham semeado o terreno fértil do pensamento dos cientistas, escritores e diretores de cinema.

Esses vínculos entre saberes científicos e populares sedimentam, no imaginário ocidental, a crença de que as necessidades de uma população humana que não pára de crescer acabarão por esgotar os recursos do planeta. Os movimentos políticos malthusianos e neomalthusianos que se desenvolveram a 
partir do século XIX o comprovam: eles preconizam severo controle da reprodução para garantir a sobrevivência da humanidade e a preservação de sua capacidade de progredir e evoluir. De fato, de acordo com seus simpatizantes, o controle da natalidade (birth control) "segue naturalmente os progressos do nível de vida e da cultura" (Faure-Soulet 1996:401). Os autores de ficção científica foram bem sucedidos na apropriação dessas idéias, como bem sabem seus fãs. Seria impossível citar todas as obras que se referem a elas. Mencionemos, a título de exemplo, os romances de J. Brunner, Stand on Zanzibar [Todos para Zanzibar] (1968); de A. Panshin, Rite of passage (1968); de Orson Scott Card, Ender's game [O jogo do exterminador ] (1977); e os filmes de Richard Fleisher, Soylent Green [ No mundo de 2020; em Portugal: À beira do fim] (1973) e de Michel Anderson, Logan's Run [Fuga do século XXIII] (1976). No entanto foi Huxley, certamente, o primeiro a levar mais a fundo a singularidade da perspectiva ocidental sobre a reprodução, e é só nos anos 1960 que o problema da superpopulação reaparece na consciência política de modo generalizado. De acordo com Clute e Niholls (1995:901), dois livros fundamentais, e que não são de ficção, contribuem para a popularização do tema: The Population Bomb, de Paul Ehrlich (1968) e The Limits of Growth: A Report for the Club of Rome's Project on the Predicament of Mankind, de D. H. Meadows et alii (1972).

A ideologia ocidental moderna, apoiada nos princípios de Malthus e de Darwin, leva os ocidentais a perceberem os povos prolíficos como submetidos às necessidades da reprodução biológica e, portanto, mais próximos da animalidade (Moisseeff no prelo; 2003; 2000). Ao mesmo tempo, devido a sua baixa taxa de fecundidade, precisam dos imigrantes, originários desses mesmos povos que consideram menos evoluídos, para garantir a renovação das gerações em suas próprias sociedades. Teme-se que a miscigenação entre indivíduos vistos como situados em patamares evolutivos supostamente diferenciados conduza à dissolução dos brancos hipoférteis e/ou a sua regressão a um estado mais animal, e esse temor torna explícita a violência das imagens produzidas nos filmes que metaforizam as relações entre 'raças' distintas, simbolicamente assimiladas a espécies diferentes. Assim, em todos os episódios de Alien, os homens e as mulheres infestados são transformados em crisálidas que explodem para dar origem a uma progenitura com características de um animal arcaico ${ }^{3}$. No filme de Richard Donaldson, Species [A experiência], de 1995, o ser híbrido originário da mistura do DNA de um extraterrestre com o DNA humano, transforma-se, ao engravidar, num animal muito parecido com um inseto. 


\section{Humanos e insetos em Hollywood}

As obras de ficção científica apresentam uma síntese simplificada e figurada das teorias científicas provenientes de diferentes disciplinas - biologia, genética, astronomia, física, antropologia, etc. - , tornando-as acessíveis a um público mais amplo de não especialistas. Ao fazê-lo, revelam a ideologia que as perpassa, ou seja, as crenças que, dentre outras coisas, deveriam explicar as diferenças entre os sexos, as espécies e as culturas. Os roteiristas americanos têm um talento especial para representar, de forma metafórica, a ideologia ocidental contemporânea: eles simbolizam as relações sociais do presente, e não as do futuro, como levaria a crer uma interpretação simplista da ficção científica. Ao pretender evocar o futuro da humanidade, libertam-se de um realismo constrangedor e privilegiam o poder de evocação das imagens. O protótipo dos terrestres humanos evoluídos é personificado pelos americanos, tidos como padrão de homem ocidental, ao passo que seus inimigos são representados por membros de uma outra espécie, geralmente insetos parasitas, gigantes e prolíficos, dotados de acelerado desenvolvimento. Esta outra espécie encarna o Outro, o menos evoluído, ou, ao contrário, como veremos, aquele que ultrapassou o estágio evolutivo humano e voltou a integrar a sociedade animal, que bane toda emoção. Em ambos os casos, o indivíduo constituiria uma parte ínfima da coletividade, à qual estaria organicamente vinculado, tal como um órgão periférico cuja existência só se justificaria pela sobrevivência do todo, em nome do qual poderia também ser sacrificado. Assim, no primeiro episódio de Alien, a ordem dada pela companhia comercial ao andróide dotado de superinteligência, por ela enviado ao espaço como cientista, é trazer para a Terra o organismo alien, ainda que para isso tenha de sacrificar a tripulação: "qualquer outra consideração é secundária", indica-lhe o computador de bordo. Os empregados da companhia, que pertencem a uma civilização superevoluída do futuro, têm como único objetivo vender essa arma biológica - utilizada pela defesa e pelos militares - a quem lhes fizer a melhor oferta.

Os insetos também remeteriam às diversas características que tanto horror inspiram aos ocidentais: a pululação, o zumbido e, como veremos adiante, o parasitismo e a supermaternidade. Sua capacidade de adaptação, relacionada à existência sob forma de larva, permite que eles proliferem e povoem qualquer tipo de meio ambiente, independentemente das mudanças climáticas ou ambientais. A propósito: não se diz que os insetos seriam as únicas espécies que sobreviveriam a uma catástrofe nuclear, assim como no passado sobreviveram, sem passar por grandes mudanças morfológicas, à queda de meteoritos? Daí o fascínio por essas espécies, 
intensificado pela descrição de sua organização social em termos antropomórficos — rainhas fecundas, operárias e/ou guerreiras, "amas"* —, tornando-as simbolicamente comparáveis às sociedades humanas. Note-se que suas atividades são apresentadas como essencialmente orientadas para a reprodução. Daí as teses dos sociobiólogos, cujo primeiro representante é E.Wilson, um entomologista: o comportamento dos indivíduos, seja ele agressivo ou altruísta, tanto nas sociedades humanas quanto animais, segue uma mesma lei fundamental, a de difundir ao máximo os seus próprios genes.

Vistas sob esse ângulo, as relações entre indivíduos ou entre populações da mesma espécie - designadas genericamente como raças, em biologia - fundam-se apenas na competição pela ocupação do mesmo território. Torna-se, então, simbolicamente possível representar, por um lado, as diferenças entre "raças" humanas — ou seja, as diferenças morfológicas e/ou sociológicas entre diferentes grupos humanos - como diferenças entre espécies em competição pelas necessidades de espaço vital e, por outro, seus respectivos continentes de origem - o Norte, o Sul, o Leste, o Oeste - como planetas distintos. A fecundidade de algumas - que tende a empobrecer os recursos nativos, levando-as a emigrar - é transformada em arma biológica. A inteligência de outras - as hipoférteis - também pode ser vista como uma arma, cujo crescimento é proporcional à diminuição da fecundidade: ela compensa o déficit demográfico e pode incitá-las a lançar mão de outras armas biológicas, como a infestação, que é o que fazem os parasitas e os vírus. Vejamos alguns exemplos desse tipo de simbolismo.

Logo no início de Starship Troopers [Tropas estelares], filme de Paul Verhoeven lançado em 1998, e cujo roteiro foi extraído do romance de Heinlein (1959), um professor explica aos seus alunos que "os insetos [bugs] são superiores aos humanos, pois se reproduzem em grande quantidade e não têm ego". Também aprendemos que os aracnídeos tornaram-se "capazes de colonizar outros planetas". A humanidade está sendo ameaçada por aracnídeos gigantes, originários do planeta $\mathrm{K}$, que atingiram tal nível de superpopulação que precisam conquistar novos territórios. Para isso, enviam asteróides que matam os terrestres aos milhões. O chefe do bando lembra um ácaro gigante, dotado de uma boca viscosa em forma de vulva, por onde sai um ferrão capaz de aspirar o cérebro dos humanos que tentam combater sua espécie; desse modo, conseguem apropriar-se dos seus pensamentos e analisá-los. Felizmente, os jovens soldados — homens e

* [N.T.] O termo francês nourrice, que designa a ama-de-leite e também a babá ou ama-seca, é igualmente aplicado à atividade das "nutridoras", as abelhas que cuidam da alimentação das larvas, nas colméias. 
mulheres - conseguem exterminar essa espécie que tenta imigrar. As imagens do filme lembram muito as das reportagens sobre a Guerra do Golfo, a ponto de nos confundir... Admitamos que essa guerra inspirou Verhoeven, e que ele substituiu por insetos gigantes e colonizadores os iraquianos que haviam invadido o Kuwait. Desse ponto de vista, a frase pronunciada por um dos heróis, no momento em que seu cérebro vai ser aspirado pelo chefe dos aracnídeos, soa como profética para Saddam Hussein, George W. Bush e suas respectivas populações: "Você vai ver: alguém como eu virá em breve e acabará com você e todos os seus malditos insetos!"

Em X-tro [Estranhas metamorfoses], filme de Harry Bromley Davenport (1983), um homem, seqüestrado por extra-terrestres três anos antes, volta à Terra para buscar seu filho. Nesse meio tempo, ele fecunda novamente sua ex-mulher e transforma a babá numa crisálida por onde saem várias dezenas de ovos, que dão origem, nos dias seguintes, a um batalhão de criancinhas. Quando aterrissa sub-repticiamente, durante a noite, tem a forma de um inseto, um tipo de bicho-pau ou de enorme gafanhoto que, para reassumir a forma humana e atingir seus objetivos, provoca seu autoengendramento: antes do nascer do Sol, ele infesta uma pobre mulher, fazendo-a morrer em terrível agonia, e sai de dentro dela na forma de homem adulto. Ele mesmo corta seu cordão umbilical e se limpa, pronto para inseminar as outras mulheres que encontrar pelo caminho. O herói de $A$ experiência II (Peter Medak, 1998), cujos genes foram infiltrados por DNAs marcianos, também não pára de inseminar mulheres, com as quais não consegue deixar de ter, compulsivamente, relações sexuais; o ventre delas explode e dá origem a meninos já crescidos, cujo destino é o de substituir os humanos, que devem ser infestados através da fecundação das suas mulheres. Mais uma vez, os imigrantes do espaço evocam aqueles, bem mais reais, do Leste e do Sul, dotados de uma fertilidade ameaçadora. Caso contrário, por que os órgãos internacionais gastariam tanta energia incitando os orientais e os africanos a controlar a fecundidade de suas mulheres? Por que insistiriam com tanta veemência no risco a que os homens dessas populações as submetem ao recusarem a contracepção ou a esterilização que os homens ocidentais lhes propõem tão generosamente?

\section{A criança vinda de fora e o homem parasita}

A saga de Alien é uma das várias versões hollywoodianas de $O$ monstro do Ártico [Thing from another world], de Christian Nyby e Howard Hawks, lançado em 1951; sem dúvida, o primeiro protótipo do gênero, seguido de 
Vampiros de almas [Invasion of the body snatchers], de Don Siegel (1956), do qual John Carpenter fez um remake, The Thing [O enigma do outro mundo] (1982), três anos após a estréia do primeiro episódio de Alien (1979). Nos anos 1950 e 1960, durante a Guerra Fria e em pleno macarthismo, essa coisa repugnante encarna perfeitamente o perigo comunista e uma eventual invasão do povo do Leste. Mas já é tempo de reconhecer que, sob pretexto de expressar o perigo representado pela invasão de uma espécie extraterrestre, esse tipo de monstro encarna a máscara medonha que designa, no Ocidente moderno que se quer emancipado dos constrangimentos biológicos, o aspecto desumano, bestial e invasor - em uma palavra, parasitário - da procriação natural (cf. Moisseeff no prelo (b); $2003 a ; 2003 b ; 2000 a ; 2000 b)$. Para corroborar essa perspectiva, lembro apenas que um dos desafios das pesquisas contemporâneas na área médica é o de dar conta do mistério do desenvolvimento de um corpo estranho (alien) dentro do corpo materno: o bebê.

Essa maneira de conceber o bebê como estrangeiro, parasita que se apodera do corpo materno, transparece nas obras de ficção-científica escritas pelos mestres do gênero: The lovers [Os amantes], conto de 1952 transformado em romance, em 1961 [Os amantes do ano 3050; em Portugal, Amor no cosmos], de P. J. Farmer (ver Moisseeff no prelo b); The midwitch cuckoos, romance de John Wyndham, adaptado para o cinema em 1960 sob o título de A aldeia dos amaldiçoados e dirigido por Wolf Rilla; refilmado, em 1995, [A cidade dos amaldiçoados] por John Carpenter; The Stranger Within [Um estranho ser], filme lançado em 1974, cujo roteirista (Richard Matheson) havia escrito, anteriormente, um conto aterrorizante sobre um monstro que podia engendrar uma mulher, intitulado Born of man and woman e lançado em 1950, ou seja, pouco antes do lançamento de The Puppet Masters, de R. Heinlein. Neste romance, adaptado para o cinema, em 1994, por Stuart Orme [Sob o domínio dos aliens], alguns aliens, criaturas extraterrestres que têm forma de moluscos, tentam subjugar a espécie humana conectando-se com o sistema nervoso dos indivíduos que tomam como hospedeiros, para controlar seus corpos e suas mentes e transformá-los em marionetes descerebradas, ou seja, sem vontade própria.

The Puppet Masters inspirou, sem dúvida, as bem sucedidas séries de TV, Os invasores [The Invaders; 1967-1968], de Larry Cohen; Arquivo X [The X-Files; 1993-2002), de Chris Carter; e First Wave (1998-2001), de Chris Brancato e Francis Ford Coppola, como também contribuiu para a criação dos "goa'ulds", os parasitas extraterrestres da série Stargate SG-1, que começou em 1997 e que ainda hoje é exibida ${ }^{4}$. Para conseguirem encarnar, os "goa'ulds" se utilizam de humanos de vários mundos como hos- 
pedeiros, transformando-os em escravos desde tempos imemoriais: sua inteligência superior teria permitido que desenvolvessem uma extraordinária tecnologia, responsável pela criação das pirâmides do Egito e da arte maia... A idéia original de Heinlein também é retomada em duas séries cult para adolescentes, criadas por Joss Whedon: Buffy, a caça-vampiros (1997-2003) e Angel (1999-2004); nos episódios intitulados "Bad eggs" ("Ovos malvados") e "Expecting" ("Esperando")*.

Em A aldeia dos amaldiçoados, todas as mulheres em idade fértil em uma pequena e pacata cidade inglesa são misteriosa e simultaneamente fecundadas - inclusive as virgens, as estéreis e aquelas cujos maridos estavam ausentes. As crianças que nascem dessa inexplicável concepção assexuada são todas semelhantes, loiras e de olhos azuis, dotadas de uma inteligência sobrenatural e de capacidades telepáticas, que utilizam para comunicar-se entre si e para ler o pensamento daqueles que lhes podem fazer mal. São desprovidas de qualquer emoção e não nutrem nenhum tipo de amor por seus pais adotivos, a quem punem deliberadamente, bem como a todos os que atravessam seu caminho. Para isso, utilizam-se do seu olhar e da sua capacidade telecinética (poder de mover os objetos à distância). Juntas, essas crianças constituem uma única entidade, comparável a um enxame vindo de lugar nenhum e com um objetivo simples: utilizar as fêmeas humanas como barrigas de aluguel - pois sua espécie perdeu a capacidade de reproduzir-se por conta própria - e tomar o lugar de uma humanidade que despreza, considerada muito inferior a si própria.

Wyndham, como a maioria dos autores de ficção científica, maneja extremamente bem a metáfora e a auto-reflexividade. Os homens ocidentais, no momento da expansão rumo a territórios desconhecidos - territórios estes dos quais tomaram posse indevidamente, durante as grandes conquistas coloniais — , também engravidaram as mulheres de 'raças' consideradas inferiores; do mesmo modo, utilizam-se hoje do poder de reprodução destas últimas, seja para aumentar sua fraca demografia, seja para adotar crianças estrangeiras, vindas necessariamente do Terceiro Mundo. Uma simples transposição nos permite imaginar que uma espécie ainda mais evoluída, que teria perdido toda a capacidade de reproduzir-se por conta própria, poderia submeter os terráqueos 'mais evoluídos' ao mesmo destino. Todavia, se a emancipação dessa espécie em relação à reprodução permite aos seus representantes atingir uma inteligência superior, a perda dos laços mais íntimos entre as crianças e os pais faria com que perdessem

* [N.T.] O título em francês: "Grossesse express" faz alusão à "gravidez-relâmpago". 
simultaneamente a capacidade de amar e ter emoções: tal como a criatura de Alien, seriam organismos desprovidos de moralidade, cuja ausência de remorso os tornaria incapazes de qualquer recuo.

Podemos encontrar nesta trama narrativa a crença ocidental que evoquei acima: quanto menos implicados estivermos no processo reprodutor, mais seremos capazes de desenvolver nossa inteligência e tecnologia (as naves espaciais e o modo de reprodução assexuado adotado pelos extraterrestres o comprovam). Desse ponto de vista, o amor materno, assimilado a uma pulsão instintiva, natural, seria uma desvantagem. Mas os autores de ficçãocientífica - freqüentemente moralistas — costumam lembrar que é importante manter um equilíbrio entre a inteligência e a emoção, se não quisermos voltar para o reino animal, que ignora qualquer noção de individualidade. Se, por um lado, o controle da reprodução é indispensável para se atingir um grau de espiritualidade superior, por outro, é crucial que ela não seja totalmente banida, para que os sentimentos sejam preservados e, conseqüentemente, não corramos o risco de cair num sistema totalitário, como o nazismo ou o comunismo. Risco ao qual sucumbiu a "raça dos senhores": os loiros de olhos azuis do Norte e do Leste da Europa. Essa eventualidade remete ao perigo que ameaça a humanidade, tendo atingido os cumes da sua evolução, o de retornar à sociedade animal. Mais uma vez, Huxley é precursor:

Entre outras coisas, a civilização consiste no processo pelo qual hordas primitivas transformam-se num equivalente grosseiro e mecânico das sociedades de insetos. No momento presente, as pressões acarretadas pelo superpovoamento e pela evolução técnica aceleram esse movimento. O cupinzeiro passou a representar um ideal atingível e até mesmo desejável, para alguns (1978 [1958]:36).

Na cosmologia ocidental moderna, a ontogênese, a sociogênese e a filogênese, que correspondem respectivamente ao desenvolvimento dos indivíduos, das sociedades e das espécies, operam com uma concepção cíclica, quase sazonal, da evolução dos fenômenos: assim como outono e inverno sucedem inelutavelmente à explosão da fertilidade primaveril e ao desabrochar estival da maturidade dos seres, também nos destinos o declínio segue irremediavelmente o apogeu. Assim como a senilidade e a esterilidade são processos normais que se sucedem ao acesso a uma fecunda maturidade, a decadência deve seguir-se à apoteose das civilizações, segundo a imagem estereotipada dos autores de história universal, que passam pelo Egito, a Grécia, Roma e os impérios chinês, otomano e americano, até profetizar o declínio próximo do Ocidente (Spengler 1923). Tal seria, também, o caso da evolução das espécies e dos planetas: depois de atingir certo 
equilíbrio, estão destinados a regredir até a extinção, como as estrelas do firmamento, que são apenas vestígios de entidades já desaparecidas, como os fósseis. O preço da emergência de novos fenômenos é o desaparecimento dos que os precederam: somos apenas poeira de estrelas, futuros dinossauros destinados a cair no esquecimento e no silêncio dos grandes espaços, de onde ressurgiremos sob uma forma totalmente diferente. 2001, uma odisséia no espaço ilustra admiravelmente essa perspectiva da involução e da metamorfose a que estamos destinados, por sermos veículos de grandes forças cósmicas e genéticas (Clarke 1968; Dumont e Monod 1970).

Na intriga subjacente às duas últimas temporadas de Arquivo $X$, as heroínas Ann, Sherry e Dana Scully são inseminadas graças à intervenção de extraterrestres, apesar de estarem a priori impossibilitadas de procriar: o marido de Ann submeteu-se a uma vasectomia para impedir que sua esposa engravidasse, pois sua última tentativa de ter um filho quase a matou; Dana Scully e o marido de Sherry são estéreis. Seus bebês desenvolvem-se de modo acelerado e são dotados de capacidades supranormais de se comunicar com suas respectivas mães, incitando-as a defendê-los contra a maledicência dos que se preocupam com estas gestações anormais. Esses bebês nascem contra tudo e contra todos, semeando o desespero ao seu redor.

Esperando [Expecting], episódio do seriado Angel que retoma o tema da gravidez extra-humana, é uma paródia de The Stranger within: um "demônio carente de paternidade" (em inglês, "procrea-parasitic demon") suborna jovens sem escrúpulo para que inseminem lindas moças humanas com seu sêmen demoníaco. O poder desse sêmen é tal, que cada uma delas engravida imediatamente de no mínimo sete bebês, que se desenvolvem em um piscar de olhos, pondo em risco a vida de suas mães-hospedeiras. Os bebês se comunicam telepaticamente com elas, incitando-as a defendê-los dos que querem eliminá-los. No momento de parir suas satânicas e desprezíveis criaturas, todas se voltam para o pai, que espera poder criar um exército para destruir a humanidade. Felizmente, Angel, o vampiro com alma, e Wesley, seu ajudante, destroem o vilão invencível - pois o fogo e a decapitação não o atingem - fazendo-o explodir em mil pedaços depois de terem-no congelado com nitrogênio líquido.

Em "Ovos malvados" ["Bad Eggs"], episódio de Buffy, a caça-vampiros, um parasita pré-histórico com aspecto de um útero gigante se desenvolve no subsolo de uma escola, onde põe seus ovos ininterruptamente, como uma fecunda rainha-inseto. Um professor, pensando tratar-se de inocentes ovos de galinha, os distribui aos alunos para que se encarreguem de cuidar deles. Por desgraça, em vez de um pintinho, cada ovo contém um animal 
monstruoso, uma espécie de enorme escorpião que, ao nascer, se enfia pelas costas de sua mãe ou pai adotivos e os transforma em autômatos. Buffy descobre o princípio dessa vampirização em um livro sobre o demônio: "Os rebentos agarram-se a um organismo hospedeiro - qualquer pessoa ao seu alcance no momento em que nascem - e assumem o controle de suas funções motoras, graças a seus neurônios de contato". Esses bebês parasitas transformam seus hospedeiros em robôs dedicados exclusivamente aos cuidados dos ovos e de sua mãe biológica, e prontos inclusive a matar para protegê-los. Uma vez inoculados, os indivíduos, tendo perdido a capacidade de pensar por conta própria, tomam o caminho que os conduz, a partir de um orifício-vagina cavado no subsolo, rumo à mãe arcaica, em volta da qual se agitam em atividade, como formigas operárias que recolhem os ovos da rainha. Felizmente, Buffy apunhala seu "bebê" com uma tesoura e consegue vencer a maléfica força maternal: ela destrói o útero gigante com um machado, depois de nele penetrar. Cada um recupera, então, a consciência. No mesmo episódio, a mãe de Buffy evoca suas idéias relativas à responsabilidade dos pais em relação aos filhos: "eles não são um fardo, mas... estou com muita vontade de falar essa palavra, fardo!"

Notemos que, nas atuais sociedades ocidentais, as crianças tendem, de fato, a ser consideradas "cronofágicas", ou seja, consumindo desbragadamente o tempo e a energia dos pais, sobretudo da mãe, transformando-a numa escrava totalmente dedicada ao filho ${ }^{5}$. Neste ponto da análise, é útil lembrar que uma nova teoria surgiu nos mais eminentes laboratórios de biogenética: os machos seriam parasitas que se utilizariam das fêmeas para reproduzir os seus genes, pois, sozinhos, seriam incapazes de fazê-lo, tal como os parasitas e os vírus (Gouyon 1995). É difícil não estabelecer um paralelo entre, de um lado, a figura do macho parasita, inoculando seus genes superiores aos das vítimas inocentes, que seriam as fêmeas, e, de outro, as criaturas malévolas dos filmes de ficção científica e de terror, que se apropriam de humanos hospedeiros para assumir um corpo, por serem incapazes de reproduzir-se entre si. Além disso, como todos sabemos, os homens vêm de Marte (Gray 1992), um planeta especial para os fãs de ficção científica e cujo nome evoca o deus da guerra na mitologia greco-romana. Portanto, os invasores vindos de fora seriam os homens, que disseminariam seu sêmen em todos os planetas. Aqui, a ficção vai ao encontro da ciência. Seria mais justo dizer que ambas inspiram-se mutuamente. Assim, nos anos 1960, o estudo dos meteoritos divulgou a idéia da panespermia interastral, que "tem origem no filósofo grego Anaxágoras (c500-428 AC)", e que havia sido rejeitada durante o século XX. Segundo essa teoria, "a vida na Terra surgiu de germes vindos de outros planetas" (Boureau 1996:112). 
A capacidade feminina de ser fecundada, ou parasitada, por um sêmen que não é seu - ou seja, a aptidão da mulher para ser uma mãe hospedeira - também remete à possibilidade de ser esta a via pela qual o diabo ou seus descendentes podem encarnar: O bebê de Rosemary [Rosemary's baby], romance de I. Levin, de 1967, levado à tela por R. Polanski; Omen [A profecia], filme de R. Donner, de 1976, seguido de dois outros episódios, em 1978 e 1982; Devil's child [O filho do demônio], de Bobby Roth, de 1997; The Sect [A seita], de Michele Soavi, de 1990, são apenas alguns exemplos. Também é comum, nos filmes de terror, que essa possessão seja mostrada no exato momento em que se torna possível, ou seja, durante a puberdade das meninas. É justamente o que acontece em O exorcista, de William Friedkin, de 1973: uma menina pré-púbere é "possuída" por forças demoníacas, quando surgem os primeiros sinais da sua nubilidade (ela se torna insuportável, grosseira, com crises de desespero, etc.); "o mal-estar ainda é mais intenso", explica um crítico de cinema, "porque Satã assume as características inocentes de uma adolescente de 12 anos", levando-nos a assistir à "desumanização de todo o seu corpo" (Morice 2001:58).

Poderíamos ser levados a pensar que, na época da igualdade dos sexos, não mais caberia evocar o poder da mulher menstruada, do qual já falava Aristóteles. No entanto, parece que o relativo encobrimento da especificidade das faculdades femininas de reprodução, associado à simetria dos papéis e direitos de cada sexo, faz jorrar nas telas de televisão, de cinema ou de ultra-sonografia o alcance desse poder no plano do imaginário. Essa capacidade feminina é associada, tanto hoje quanto no passado, às "forças das trevas", aos "demônios" — com os quais a mulher tem contas a ajustar — que teriam de ser sistematicamente exorcizados a cada nova geração feminina (ver a mencionada série para adolescentes, Buffy, a caça-vampiros).

Os cavaleiros do Apocalipse, agentes de Satã, são hoje representados pelos pesquisadores da área biotecnológica, o que é ilustrado por várias obras, dentre as quais citaremos apenas o livro Mutation [Mutação], de Robin Cook (1989) e o filme O enviado [Godsend], de Nick Hamm (2004). Destacamos, também, que esses pesquisadores não desprezam a eventual ajuda dos extraterrestres (ver, entre outros, Arquivo X).

\section{Mulheres, insetos e clones}

A apropriação dos poderes femininos pelos homens é um tema que perpassa os ritos e mitos mais tradicionais. Ela serve para justificar a superioridade masculina e o papel dos homens como iniciadores de meninos e meninas, 
de homens e mulheres. Dá-se o inverso na mitologia contemporânea, que procuro aqui destrinchar: aqueles que tentam monopolizar os poderes reprodutores da mulher (os militares, os biotecnólogos, os extra-terrestres) estão do lado dos maus, do lado de Satã e de seus adoradores. Pois à ideologia ocidental subjaz o temor de que uma reprodução descontrolada, a do Terceiro Mundo, venha a substituir uma 'civilização' dita evoluída por outra, considerada mais próxima da animalidade. A reprodução remete menos à perpetuação da espécie do que à anulação pela superpopulação ou pela substituição - uma espécie ou uma população podendo, assim, suplantar outra. Conseqüentemente, a fertilidade feminina não dominada nos países em desenvolvimento é apresentada como um perigo para o conjunto da humanidade. À diferença do que vigora em outras culturas, a desgraça e a fatalidade remetem, no Ocidente, não à esterilidade, mas a um excesso de fertilidade. Dominar a reprodução dos pobres através do controle do ventre das mulheres tornou-se um dos objetivos maiores do mundo 'civilizado'. Os filmes de ficção científica deixam explícita essa ideologia: os monstros procriadores postos em cena personificam os estrangeiros, os aliens, cujas hordas vindas do sul e do leste ameaçam submergir o Ocidente. E entre esses monstros e o medo em relação aos jovens dos subúrbios, percebidos como predadores potenciais, não há talvez mais do que um passo de formiga gigante.

Compreende-se melhor agora, assim espero, por que os insetos constituem personagens favoritos nas obras que mencionei. Sua capacidade de proliferar está ligada a seu modo específico de reprodução, que constitui o tema de muitos documentários, nos quais as formigas e as abelhas têm lugar privilegiado. São mencionadas as espécies vindas da África ou da América do Sul, capazes de invadir os territórios do Norte e substituir as espécies nativas, menos agressivas, mais pacíficas e, portanto, menos aptas a sobreviver face a tais guerreiras - e tudo isso é retomado pelos filmes de horror de tipo B (por exemplo, The savage bees [As abelhas selvagens], de Bruce Geller (1976) ou Legion of fire: killer ants! [A volta das formigas assassinas], também conhecido sob o título de Marabunta, de Jim Charleston e George Manasse (1998). Também recebem destaque o papel da fêmea reprodutora - a que põe os ovos, a "rainha" - e o aspecto particularmente cruel de sua função (ver o desenho animado Antz [Formiguinha Z], de Paul Dix (1998).

A figura da rainha, escrava do processo reprodutivo de sua espécie, serve de referência para simbolizar a parcela de liberdade da qual, por comparação aos homens, as mulheres estão privadas em virtude do papel que só elas têm durante a gestação. Ora, é exatamente por assumir sozinha a reprodução da colméia que a rainha dos insetos chega a perder as caracte- 
rísticas morfológicas habituais dos outros membros da espécie: seu abdome, distendido, fica gigantesco em comparação com o resto do corpo. Os roteiristas concentram o foco na metamorfose monstruosa por que passa a fêmea quando assume seu papel reprodutor. Assim, no último episódio de Alien, a ressurreição, o espetáculo do parto é aflitivo, a rainha alien tendo adquirido, graças à hibridação com uma mulher — a tenente Ripley —, um sistema reprodutor completo que lhe permite dar à luz sua progenitura, sem que esta passe por organismos hospedeiros. Tudo é feito para revelar o aspecto monstruoso do parto "natural" e uterino. A rainha jaz em seu leito de dor, composto de substâncias pegajosas, quase excrementícias, "um lago pestilento" (Crispin e Whedon 1997:261).

um grito ressoa ainda mais agudo que os outros [...]. O ventre da rainha se expande [...]. Ripley [...] olhava a rainha, que se debatia e gritava no lodo e no muco, e essa paródia obscena daquilo que ela mesma havia experimentado davalhe náuseas. [...] o ventre inflado e ondulante, dilacerações horriveis, a pressão inexorável. A rainha [...] bramiu e tentou levantar-se de seu leito fétido. Um jato de sangue bruscamente saiu como um gêiser do ventre da rainha. A fêmea gritava ainda [...]. A criatura que se contorcia afundou no imundo lodaçal [...] Houve um último grito, um ruído assustador, e o Recém-Nascido emergiu dos exíguos confins do útero materno (Crispin e Whedon 1997:247-251)

Esse tipo de cena de aspecto repugnante sugere que a parte da mulher sujeita às forças genésicas, seu útero, é, como o polegar do panda, o resto já inútil de um estágio anterior da humanidade. Desse ponto de vista, o papel da mulher na reprodução exprimiria a persistência de sua parte animal, distinguindo-a do homem, desprovido desse apêndice arcaico. E como a transformação da mulher em procriadora virtual se dá na puberdade, escritores e roteiristas podem exercer seu talento, representando a puberdade feminina sob a forma de uma transformação radical, uma verdadeira metamorfose: a bela ninfeta, uma vez possuída pelas forças genésicas, adquire os traços de uma fêmea de outra espécie cujo paradigma é o inseto, a rainha fecunda, revelando, assim, sua verdadeira natureza de monstro arcaico, perigoso e mortífero (ver Farmer 1952 e 1961).

Nessa perspectiva, outro aspecto do modo de desenvolvimento dos insetos joga a seu favor na cena hollywoodiana: os estágios sucessivos pelos quais eles passam para chegar a sua forma definitiva - ovo, larva, ninfacrisálida, inseto adulto propriamente reprodutor (imago). Essa metamorfose serve para simbolizar a transformação dos adolescentes durante a fase da puberdade - quer dizer, a passagem de um estado estéril a um estado 
fértil. Assim, em A experiência [Species], o roteirista associa a fase púbere de uma alien originada de um DNA terrestre, à passagem por um estado de crisálida, da qual surge uma reprodutora plenamente desenvolvida. A menina até então inofensiva é apresentada, na ocasião em que atinge sua potência reprodutiva, como se estivesse transformando-se em uma predadora que procura ter relações sexuais com o único objetivo de reproduzir-se; ela mata seus parceiros sexuais assim que eles cumprem seu papel, como a viúva negra e a fêmea do louva-a-deus.

A puberdade revela, de certo modo, a natureza insetóide da mulher; pois quando suas forças genésicas, até então adormecidas, despertam e manifestam-se, seu corpo aparece como um organismo infestado por germes de vida: centenas de ovos vindos de um além ou aquém do humano, dos quais podem eclodir criaturas totalmente outras. Afinal, a mulher não gera um ser completamente outro quando dá à luz um menino? É isso que é encenado por Alien, a ressurreição: a rainha, tendo adquirido um aparelho reprodutor humano, é capaz de dar à luz o primeiro macho de sua espécie, um híbrido, metade humano, metade animal. Desse ponto de vista, a animalidade - assim como o DNA arcaico mitocondrial - é herdada da linha materna: passa de mãe para filha e, desafortunadamente, é transmitida aos filhos que, no entanto, são mantidos à distância do lugar de incubação de sua prole: o útero materno. Por este motivo freqüentemente considera-se que estes últimos têm uma ligação privilegiada com o transcendente, a sobrenatureza, a técnica, isto é, o que ajuda a dominar a Mãe natureza (Moisseeff 1995, 1998).

Mas, de acordo com informações obtidas na Internet, há outra passagem do roteiro original desse episódio, especialmente reveladora e que, infelizmente, acabou sendo eliminada. Ela deveria suceder às primeiras imagens que mostram o surgimento da nova Ripley, clonada a partir da sopa primordial de DNA colhida do caldeirão infernal do terceiro episódio:

Vista aérea de um campo de trigo dourado preenchendo a tela e contrastando fortemente com a cena anterior. Uma mulher caminha por esse campo, seguida de perto por uma menina com um vestido leve e surrado. Voz da menina: "Mamãe sempre me disse que os monstros, os verdadeiros monstros, não existiam, mas eles existem". A menina pára e olha à sua volta. O trigo chega à altura do seu peito e assim percebemos que ela não pode ver o que está mais além. Ela se volta para ver a mulher, mas esta já está distante uns 50 metros. A expressão do rosto da menina reflete sua súbita perplexidade. Ela esmaga um bichinho em sua nuca e o tira com a mão, onde o inseto carnudo fica se debatendo. Ela tem agora a fisionomia ainda mais transtornada, mas não con- 
segue emitir um som sequer. O som dos insetos invade o ar. Outro inseto pousa nela, depois outro, e mais outro ainda. Ela olha para o chão, cada vez mais horrorizada, e vê a seus pés uma poça de sangue que vai aumentando até cobrir o campo de trigo, um mar de sangue negro e espesso. A menina tenta ainda gritar, levanta os braços (como para se proteger). Ela está agora inteiramente coberta de insetos, uma mortalha negra e pulsante recobre seu corpo, e quando, enfim, ela grita, a nuvem se precipita para dentro de sua boca.

Evidentemente, é difícil não ver, aqui, a representação simbólica do trauma que é, para a menina, a primeira menstruação. Mas por que associá-la aos insetos, senão para identificar o acontecimento a uma mutação provocada por uma infestação? A mortalha que os insetos compõem evoca a crisálida no interior da qual se opera sua metamorfose em mãe potencial possuída, penetrada pelos germes vitais. No filme de Brian de Palma, Carrie [Carrie, a estranha] (1976), baseado no primeiro romance de Stephen King (1974), a adolescente também se assusta quando descobre, ao tomar banho no vestiário do colégio, o aparecimento das primeiras regras. Uma vez na puberdade, sua inocência transforma-se em uma força fenomenal que lhe permite vingar-se de todos, destruindo-os com um único olhar. Mas voltemos à iniciação de Ripley. Algumas cenas após aquela que acabo de reconstituir, a partir do roteiro original, somos levados a assistir à sua cesariana torácica. De seu peito aberto emerge a pequena rainha, da qual ela estava grávida, no episódio precedente. Ficamos sabendo que a mistura de seus genes fez com que Ripley e a rainha adquirissem, cada uma delas, a aptidão especial da outra. A rainha tem, agora, um aparelho reprodutor completo. Seu corpo torna-se, de fato, a metáfora do aparelho reprodutor feminino de Ripley, que lhe foi extirpado para completar sua iniciação. Mais tarde, em seu aposento, após haver parido o seu outro eu, Ripley está totalmente envolta em um pano translúcido - uma espécie de crisálida — de onde ela sai usando as unhas que, nesse meio tempo, tornaram-se garras animais. Por que colocar a heroína em uma crisálida, senão para assinalar a metamorfose pela qual ela acaba de passar após o parto? Uma mulher que se tornou capaz de dar a vida de reproduzir por si própria sua função reprodutiva (o aparelho reprodutor de sua filha) — é definitivamente híbrida: seu genoma é heterogêneo, metade humano, metade animal, e sua beleza é uma máscara que recobre a parte animal que ela acaba de exprimir ao dar à luz.

Como todas as mulheres, Ripley e sua filha são híbridas, isto é, humanas e animais, pois são capazes de engendrar a partir de seus corpos. Depois dessa experiência tão singular, Ripley mostra-se muito menos interessada pelo futuro da humanidade: a preocupação materna primária — tão 
cara aos psicanalistas - a impede de sentir imediatamente qualquer compaixão por aqueles — os humanos — que não sejam membros de sua nova pequena família, a qual, entrementes, proliferou. Para ela, salvar a humanidade já não é prioridade, e ela se recusa a um novo sacrifício. Será necessária a intervenção de uma robô de segunda geração - um robô feminino gerado por outro robô, isto é, totalmente desconectado da reprodução natural - para que ela recupere a alma que perdeu no processo da maternidade. Eis a idéia subjacente: uma mulher que se tornou mãe já não é exatamente a mesma, não é equivalente a um homem; é um híbrido que egoisticamente procurará defender sua progenitura, antes dos demais congêneres. Ela se torna uma filha de Eva e não uma cria de Maria. O Cristo não é mais uma figura da redenção com a qual tenta se identificar.

A heroína de $A$ experiência [Species], conforme já mencionei, também sofre uma metamorfose ao transformar-se em reprodutora. Os sinais precursores de sua mutação são bem conhecidos dos especialistas em adolescência: ela fica bulímica (ingurgita com as mãos grandes quantidades de comida fria) e dismorfofóbica (ao olhar-se no espelho, tem a impressão de que seu rosto começa a apresentar deformações horrendas, que a fazem chorar). Algum tempo depois, ela efetivamente se transforma em crisálida, uma espécie de câmara negra onde permanece isolada do mundo, mas de onde ressurgirá como uma loura estonteante, de formas extremamente femininas: uma potência sexual que atrai todos os olhares masculinos. Sua beleza é apenas uma armadilha, a isca com que captura suas presas masculinas para por elas ser inseminada. Seu lado medusa transparece então: tentáculos lhe saem do corpo, imobilizando as vítimas que ela tenta matar após ter sido impregnada de seu sêmen. Em A experiência 2 - a mutação [Species $I I]$, os filhos do macho humano cujo DNA foi infiltrado de genes marcianos também têm a capacidade de se transformar em crisálidas: essas dezenas e dezenas de meninos que nasceram matando a mãe alcançam o teto graças a tentáculos que saem de seus narizes. Eles formam, então, casulos de onde eclodirão os predadores inseminadores, cada um deles pronto, assim como seu pai, a infestar a humanidade.

No seriado Buffy, a caça-vampiros, aparecem constantes referências a magia, rituais de exorcismo e metamorfoses - em vampiro, em lobisomem e em outro animal mais ou menos fantástico. Essas modificações não poderiam evocar melhor a metamorfose por que passam os adolescentes, ao se tornarem procriadores potenciais. Em um episódio do início da série, uma linda professora de ciências naturais seduz seus alunos machos e virgens. Ela os atrai à sua casa, onde se transforma em louva-a-deus. Na jaula onde os mantém prisioneiros, obriga-os a inseminar seus ovos enquanto 
devora-lhes a cabeça. Graças a Deus, Buffy acaba cortando-a em pedacinhos. Os adolescentes de hoje, como os do Admirável mundo novo, onde se ensina a praticar "exercícios malthusianos", estão prevenidos: sexo, sim; reprodução, não! Nos diferentes episódios de Scream [Pânico], de Wes Craven e Kevin Williamson (1996, 1997, 2000), que os adolescentes adoram, apenas virgens - rapazes ou moças - são ameaçados pelo assassino louco... Os preservativos e a contracepção aparecem, então, claramente como os únicos meios eficazes de atravessar sem perigo o mar revolto da metamorfose da puberdade.

\section{Vivíparos ou clones: somos obrigados a escolher?}

A moral das histórias que acabo de contar é simples: a mulher, da puberdade à menopausa, tem todo o interesse em submeter-se a uma contracepção liberadora, e a humanidade evoluída tem igual interesse em desenvolver outros modos, artificiais, de reprodução, em vez de permanecer subordinada à mãe Natureza; pois a natureza tem seus próprios objetivos, que estão longe de ser sempre favoráveis àqueles a que os homens aspiram (Bloom 1995). Mas enquanto esperam o advento do Admirável mundo novo, homens e mulheres tendem a estar associados, no imaginário popular, a duas espécies distintas — provenientes de dois planetas diferentes: Marte e Vênus... —, mutuamente dependentes: os homens, que não dão à luz, necessitam das mulheres para engendrar seus semelhantes, enquanto as mulheres necessitam dos homens para ascender um degrau na escala da evolução.

É possível imaginar, a exemplo de Huxley, um mundo em que a procriação artificial, in vitro ou por clonagem, seria generalizada. Caducaria, então, a necessidade do encontro dos sexos. Na miragem utópica aparece um universo novamente constituído de dois planetas separados: um, povoado de mulheres; outro, de homens. Cada um dos dois sexos, depois de haver caminhado lado a lado, por uma longa história comum na Terra, acostaria seu respectivo planeta de origem e lançaria âncora para aí fixarse definitivamente. Nenhuma necessidade de deslocar-se em busca de sua outra metade; cada um viveria entre semelhantes e se reproduziria identicamente: adeus vivíparo, olá clone! A não ser que as fêmeas, esses seres vivíparos, se apropriem das reservas espermáticas de seus homólogos masculinos, transformando-os - a exemplo da rainha dos insetos em escravos de seu processo reprodutor. É o que profetizam certos autores da ficção científica, descrevendo sociedades humanas matriarcais: vejam-se, entre outros, La Jeune fille et les clones [A menina e os clones], de David 
Brin (1993); Chroniques du Pays des Mères [Crônica do país das mães], de Elisabeth Vonarburg (1999); Pollen [Pólen], de Joëlle Wintrebert (2002); para a descrição da tentativa de implementação, já em nossa época, de tal sistema, "graças" à aparição de uma doença que afeta apenas os homens entre a puberdade e a andropausa (ver Les hommes protégés [Os homens protegidos], de Robert Merle, 1974).

Podemos, agora, avaliar aquilo que é encoberto pela violência das imagens da procriação nos filmes de ficção científica: concentrando-se na mitologia derivada da ideologia ocidental, ela exprime aquilo que subjaz a essa ideologia. Supõe-se que a quantidade de energia que uma espécie, uma cultura ou o gênero feminino consagram à reprodução, sobrepuja a capacidade de desenvolver-se e de transmitir conhecimentos - em outras palavras, usurpa a cultura. A natureza é a biologia, a biologia são as modalidades de transmissão da vida. Por outro lado, a cultura está ligada às atividades 'artificiais' de produção, isto é, não programadas pelo dever de sobrevivência biológica. Em conseqüência, o saber popular associa o arcaísmo de uma espécie, de uma cultura, ou de um gênero, à sua propensão a conceder supremacia às atividades reprodutivas. A parte essencial que cabe à mulher no processo reprodutivo - a saber, a gestação e o instinto materno a ela associado - poderá, então, ser pensada como um obstáculo à sua evolução. Assim, na imaginação popular, a transformação de uma mulher em mãe potencial ou de fato é apresentada como verdadeira metamorfose, que exprime seu pertencimento a uma espécie escrava das necessidades de reprodução biológica. A mulher grávida torna-se fêmea prenhe, seu estado de gestante a faz regredir a um estágio infra-humano, animal, o de uma pobre vivípara. Tender-se-á, então, a opor às virtudes do amor e da volúpia sexual liberada do jugo reprodutor, os perigos da involução a que a reprodução feminina expõe os homens. Agradeçamos, portanto, a Huxley, por ter desempenhado o papel de Cassandra, às vésperas do advento do Terceiro Reich e de sua biopolítica mortífera. E em uma última homenagem, reconheçamos com ele o encanto dos vivíparos arcaicos que somos ainda.

Ao fim dessa apresentação, torna-se evidente que são muitas as obras de antecipação que abordaram a reprodução, e que elas refletem a evolução contemporânea das representações e das práticas ocidentais relativas à diferença dos sexos e às distinções culturais. Reduzindo-as a uma distinção entre espécies, as poderosas imagens que essas obras são capazes de construir ou de inspirar revelam a violência das relações entre as sociedades e a ideologia racista subjacente. Desse ponto de vista, elas podem constituir suportes ao desenvolvimento de uma reflexão ética que não concerne apenas ao futuro das práticas científicas, mas também ao das relações entre culturas. Na França, o caso do 
véu oriental é mais um avatar do combate a que os homens se aplicam para impor sua perspectiva sobre o mundo, o sexo e a reprodução (Moisseeff, no prelo (a) - uma batalha cosmológica de que nos dão conta as space opera.

Recebido em 15 de dezembro de 2004

Aprovado em 14 de março de 2005

Tradução de Amir Geiger e Simone Pondé Vassalo

Marika Moisseeff é "chargée de recherche" no Laboratoire d'Anthropologie Sociale, no CNRS (Centre Nationale de la Recherche Scientifique), Paris. Email: <marika.moisseeff@college-de-france.fr>

\section{Notas}

*Alguns trechos deste trabalho já foram publicados em Moisseeff, no prelo (b), 2003a e 2003b, 2000a e 2000b. Uma versão modificada deste artigo será publicada na revista Anthropologie et Societés, 29(2), 2005.

${ }^{1}$ Nos ovíparos, "o embrião não se desenvolve a partir do tecido materno", mas no ovo, ao contrário do que ocorre com os vivíparos (ver os verbetes ovíparo e vivíparo do dicionário Le Petit Robert; grifos meus).

${ }^{2}$ Alien, o oitavo passageiro [Alien], de Ridley Scott (1979); Alien, o resgate [Aliens], de James Cameron (1986); Alien 3, de David Fincher (1993); Alien, a ressurreição [Alien: Ressurrection], de Jean-Pierre Jeunet (1997); Twenthieth Century Fox Film Corporation.

${ }^{3}$ Apesar de Alien compartilhar com outros insetos — como a formiga, a aranha, o louva-a-deus - algumas características morfológicas, fisiológicas ou de organização social, sua silhueta evoca o esqueleto de um dinossauro, isto é, um animal pré-histórico há muito tempo já extinto. Nos filmes de terror ou de ficção científica, o recurso a espécies pré-históricas e, principalmente, a répteis gigantes assinala a perigosa reaparição de um dado arcaico, ou seja, o risco de involução ou de extinção da humanidade. Nesse sentido, o fato de a menininha do segundo episódio se chamar Newt, que em inglês significa pequena salamandra, não é fortuito: a salamandra certamente não desapareceu, mas foi classificada como pertencendo 
ao grupo dos animais muito antigos e ao do bestiário fabuloso. Sua pele produz, inclusive, uma secreção altamente corrosiva que evoca estranhamente a dos aliens.

4 A série é baseada em história e personagens imaginados por Dean Devlin e Roland Emmerich; estreou no cinema em 1994, e foi adaptada para a televisão por Jonathan Glassner e Brad Wright.

${ }^{5}$ Aquilo que Winnicott, psicanalista infantil, designava "preocupação materna primária": ao final da gestação e durante as semanas seguintes ao nascimento, a mãe desenvolveria um interesse exclusivo por seu recém-nascido (ver Chiland 1985:35; Winnicott 1958 [1956]).

\section{Referências bibliográficas}

BLOOM, H. 2001 [1995]. Le principe de Lucifer. Paris: Le Jardin des Livres. BOUREAU, E. 1996."Origine de la vie." Encyclopædia Universalis, vol. 17. Paris. pp.113-122.

BRIN, D. 1997 [1993]. La jeune fille et les clones. Paris: Pocket.

BRUNNER, J. 1972 [1968]. Tous à Zanzibar. Paris: Editions J'ai Lu.

CARD, O. S. 1994 [1977]. La stratégie ender. Le cycle d'ender 1. Paris: Editions J'ai Lu.

CHILAND, C. 1985. "Psychoses et névroses de l'enfant dans l'oeuvre de Winnicott." In: S. Lebovici et alii (orgs.), Traité de psychiatrie de l'enfant et de l'adolescent. Tome II. Paris: Presses Universitaires de France. pp. 33-40.

CLARKE, A. C. 1968. 2001, l'odyssée de l'espace. D'après un scénario original de Stanley Kubrick et Arthur C.
Clarke. Paris: Robert Laffont.

CLUTE, J. e NICHOLLS, P. (eds.) 1995. The encyclopedia of science fiction. New York: St Martin's Griffin.

COOK, R. 1989. Mutation. Paris: Editions Sylvie Messinger.

CRISPIN, A. C. e WHEDON, J. 1997. Alien: la résurrection. Paris: Editions J'ai Lu.

DARWIN, C. 1992 [1859]. L'Origine des espèces au moyen de la sélection naturelle ou la préservation des races favorisées dans la lutte pour la survie. Paris: GF Flammarion.

DUMONT, J. P. e MONOD, J. 1970. Le Fœtus astral. Paris: Christian Bourgois Editeur.

FARMER, P. J. 1961.The lovers. New York: Ballantine Books. Tradução francesa: Les amants étrangers. Paris: Editions J'ai Lu. 1990 [1968]. FAURE-SOULET. 1996. "Malthusianis- 
me et néomalthusianisme". Encyclopæedia Universalis, vol.14. Paris. pp.400-402.

FOUCAULT, M. 1997 [1976]. "Du pouvoir de souveraineté au pouvoir sur la vie. Cours du 17 mars 1976." In: _. Il faut défendre la société. Cours au Collège de France. Paris: Gallimard Seuil. pp.213-235.

GOUYON,P. H. 1995. "Sexe et évolution: l'autre et le soi génétiques". Turbulence, 1:1-8.

GRAY, J. 1997 [1992]. Les hommes viennent de Mars, les femmes viennent de Vénus. Paris: J'ai Lu.

HEINLEIN, R. 1994 [1951]. The puppet masters. New York: Del Rey.

. 1997 [1959]. Starship troopers. New York: Ace Books.

HUXLEY, A. 1998 [1932]. Le meilleur des mondes. Paris: Pocket. 1978 [1958]. Retour au meilleur des mondes. Paris: Pocket.

KING, S. 1976 [1974]. Carrie. Paris: Editions J'ai Lu.

LEVIN, I. 1968 [1967]. Un bébé pour Rosemary. Paris: Editions Robert Laffont.

MANIER, B. 1995. "Des femmes seules avec enfants". Les Enfants du Monde, 26:9-12, Revue de l'UNICEF.

MALTHUS, T. R. 1980 [1798]. Essai sur le principe de population en tant qu'il influe sur le progrès futur de la société. Paris: Institut National d'Etudes Démographiques/ Presses Universitaires de France. . 1964 [1803]. Essai sur le principe de population ou exposé de ses effets sur le bonheur humain, dans le passé et le présent avec des recherches sur nos perspectives de supprimer ou de diminuer à l'avenir les maux qu'il occasionne. Genève: Gonthier.

MATHESON, R. 1999 [1955]. "Né de l'homme et de la femme." In: Derrière l'écran. Intégrale des nouvelles, Volume 1 .Paris: Imagine Flammarion.

MERLE, R. 1974. Les hommes protégés. Paris: Gallimard.

MOISSEEFF, Marika. 1992. "Les enjeux anthropologiques de la thérapie familiale avec les adolescents". In: C. Gammer e M. C. Cabié (éds.), L'adolescence, crise familiale. Thérapie familiale par phases. Toulouse: Editions Erès. pp.205-227.

1995. Un long chemin semé d'objets cultuels: le cycle initiatique aranda. Paris: Editions de l'Ecole des Hautes Etudes en Sciences Sociales (Coleção Cahiers de l'Homme). . 1998. "Rêver la différence des sexes: quelques implications du traitement aborigène de la sexualité". In: A. Durandeau et alii (org.), Sexe et guérison. Paris: l'Harmattan. pp.45-74.

2000a. "Une figure de l'altérité chez les Dentcico ou la maternité comme puissance maléfique". In: J. L. Jamard et alii (org.), En substances. Textes pour Françoise Héritier. Paris: Arthème Fayard. pp. 471-489. 2000b. "Pacs, parité, viviparité: un aller-retour de l'utopie au mythe". Che vuoi?, 13:53-62. . 2003a. "Alien ou la science-fiction 
comme mythologie contemporaine" Nouvel Observateur, hors série 'Lévi-Strauss et la pensée sauvage', juillet:82-85.

2003b. "Une femme initiée en vaut ... deux: de l'île aux femmes polynésienne à l'Alien américaine". In:

A. Babadzan (org.), Insularités. Hommage à Henri Lavondès. Nanterre: Société d'Ethnologie. pp. 79-107.

no prelo (a). "Quelles sciences sociales pour penser le métissage?". Actes du Colloque L'expérience Métisse (2-3 avril 2004, à l'Auditorium du Louvre). Disponível no site do Musée du Quai Branly.

no prelo (b). "L'amour extraterrestre: une mythologie à méditer". In: F. Héritier et M. Xanthakou. Corps et affects. Paris: Editions Odile Jacob.

MORICE, J. 2001. "L'Exorciste. Le classique du film d'horreur de Friedkin. Ressort, enrichi de onze minutes". Télérama, 2670:58.

PANSHIN, A. 1973 [1968]. Rite de passage. Paris: Editions Opta.

ROBERT, P. 1995. Le nouveau petit Robert. Paris: Dictionnaire Le Robert.
SERRE, J. L. 1984. "De Malthus à Darwin: évolution ou révolution du concept de lutte pour la survie". In: A. Fauve-Chamoux (org.), Malthus hier et aujourd'hui. Paris: Editions du CNRS.

SORG, C. 1999. "C'était comment l'an 2000?". Télérama, 2607:12-13.

SPENGLER, O. 1976 [1923]. Le déclin de l'Occident. Esquisse d'une morphologie de l'histoire universelle. Paris: Gallimard.

SWIFT, J. 1988 [1729]. "Modeste proposition concernant les enfants des classes pauvres". In: OEuvres. Paris: Gallimard (Coleção La Pléiade).

VAN GENNEP, A. 1981 [1909]. Les rites de passage. Paris: A. et J. Picard

VONARBURG, E. 1999. Chronique $d u$ pays des mères. Québec: Editions Alire.

WINNICOTT, D. W. 1958. Collected papers through paediatrics to psychoanalysis. Londres: Tavistock Public. Tradução francesa: De la pédiatrie à la psychanalyse. Paris: Payot, 1969.

WINTREBERT, J. 2002. Pollen. Paris: Editions Au Diable Vauvert 


\section{Resumo}

Ainda que os etnólogos afirmem que os mitos estão presentes em todas as sociedades, eles tendem, no entanto, a debruçar-se sobretudo sobre aqueles recolhidos em outras sociedades e/ou escritos em outra época. A análise de um conjunto representativo de obras de ficção científica, que têm como tema a reprodução, permite sugerir que a ficção científica constitui um corpus mitológico, no sentido próprio do termo. Ela revela os alicerces da ideologia ocidental contemporânea, concernentes a diferenças sexuais e culturais. Estamos, então, em posição de avaliar a pregnância persistente da ideologia evolucionista e do racismo que ela veicula. Levar a sério a imageria popular ocidental contemporânea permite recuperar certos aspectos mais gerais da mitologia, comumente negligenciados: a auto-reflexividade e o questionamento ético que ela proporciona.

Palavras-chave Mito, Sexo, Procriação, Ficção Científica, Alien

\section{Abstract}

Although anthropologists maintain that myths exist in all societies, they tend to concern themselves with myths collected elsewhere and/or written in other time periods. The analysis of a representative sample of works of science fiction dealing with the theme of reproduction suggests that science fiction is, properly speaking, a mythological corpus. It reveals the underpinnings of contemporary Western thought regarding sexual and cultural difference, and underscores the persistence of an evolutionist, and therefore racist ideology. Taking contemporary Western popular imagery seriously reveals the importance of certain general, albeit largely neglected aspects of mythology: auto-reflexivity and the ethical questioning it implies.

Key words Myth, Sex, Procreation, Science fiction, Alien 